DOI: $10.15193 /$ zntj/2017/113/209

\author{
MICHAŁ ŚWIECA, MONIKA KORDOWSKA-WIATER, MONIKA PYTKA, \\ ŁUKASZ SĘCZYK, URSZULA GAWLIK-DZIKI
}

\title{
APPLYING SPROUTS OF SELECTED LEGUMES AS CARRIERS FOR LACTOBACILLUS RHAMNOSUS GG - SCREENING STUDIES
}

\begin{abstract}
S u m m a r y
Probiotics and prebiotics play an important role in human and animal nutrition. Those research studies were performed to evaluate the potential of using legume sprouts as carriers for probiotic strain of Lactobacillus rhamnosus GG. They determined the effect of legume species, temperature of sprouting, and inoculation methods of seeds or growing sprouts on the survival and/or growth of probiotics.

It was found that the count of bacteria in sprouts depended on the germination temperature, inoculation methods as well as on the species of legume used as a carrier. The beans examined (Adzuki and Mung) germinated effectively at a temperature between $25 \div 35^{\circ} \mathrm{C}$. And the lentil sprouted most effectively at $25{ }^{\circ} \mathrm{C}$. In the case of soy-bean and lentil, the temperature of $35^{\circ} \mathrm{C}$ caused the germination efficiency to decrease. The growth of Lb. rhamnosus GG was reported only in the case of the lentil and soy-bean sprouts obtained from the seeds imbibed in an inoculum and germinated at $25^{\circ} \mathrm{C}$. The count of probiotic bacteria was $3.1 \times 10^{6}$ and $7.18 \times 10^{6} \mathrm{CFU}$ per grams of fresh mass, respectively. The sprouts obtained from the bean seeds analyzed did not provide any conditions for probiotic bacteria to survive and grow. The best carrier for the probiotic bacteria studied were the soy-bean sprouts; in their case, after inoculation of seeds and using a suspension of probiotic bacteria, the sprouts obtained at $25{ }^{\circ} \mathrm{C}$ had the best quality parameters.
\end{abstract}

Key words: legumes, sprouts, probiotics, Lb. rhamnosus

\section{Introduction}

The consumption of probiotics is usually associated with healthy diets and an increase in consumer wellness [3]. Probiotics (or their metabolites) reduce the risk of cancer, improve heart health, enhance the immune system, reduce menopause symp-

Dr hab. M. Świeca, mgr inż. Ł. Sęczyk, dr hab. U. Gawlik-Dziki, Katedra Biochemii i Chemii Żywności, dr M. Kordowska-Wiater, dr M. Pytka, Katedra Biotechnologii, Mikrobiologii i Żywienia Człowieka, Wydz. Nauk o Żywności i Biotechnologii, Uniwersytet Przyrodniczy w Lublinie, ul. Skromna 8, 20-704 Lublin.Kontakt:michal.swieca@up.lublin.pl 
toms, enhance gastrointestinal health, preserve urinary tract health, decline osteoporosis, protect vision and exhibit antibacterial, anti-inflammatory and antiviral activities [4]. Many studies have confirmed those positive effects in in vitro studies as well as in in vivo animal or/and human models [4, 27].

Probiotics have been incorporated into several food products and supplements; most of them are dairy products, such as cheeses, dairy desserts, ice-cream, fermented milk products, or fermented vegetables [24]. However, in recent years, novel alternative matrices for probiotics have been developed, e.g., chocolate or meat products [3, 18]. Moreover, the need for new probiotic products has drawn attention owing to the growing interest in veganism and the higher number of consumers with diet restrictions such as lactose intolerance, allergies, and cholesterol restriction [7, 10, 19].

In modern functional food, probiotic microorganisms are usually combined with prebiotics. Prebiotic is a selective substrate for one or a limited number of probiotics strains. Prebiotics stimulate the growth and survival of probiotic strains and, consequently, they are able to alter the colonic microbiota of the host toward a healthier composition. Legumes are considered to be an excellent source of nutrients and compounds with well-documented pro-health properties, e.g., phenolics or vitamins $[8,13$, 22]. Additionally, beans contain high amounts of resistant starch, which may predispose them to be effective prebiotics $[1,11,12]$.

The objective of the study was to research on the possibility of using legume sprouts as carriers for $L b$. rhamnosus GG. The study was focused on selecting the legume species, conditions of germination, and methods utilized to inoculate seeds/sprouts with a probiotic strain.

\section{Materials and methods}

\section{Materials}

All chemicals used to cultivate sprouts and microbiological media were purchased in the Sigma-Aldrich Company (Poznan, Poland) and BTL Ltd. (Łódź, Poland). Soybean, lentil, Adzuki bean, and Mung bean seeds were purchased in the PNOS S.A., Ożarów Mazowiecki, Poland.

An Lb. rhamnosus GG strain was used in this study. The strain was isolated from a commercial probiotic preparation. It was identified microscopically, by biochemical tests, and by $16 \mathrm{~S}$ rDNA sequencing. The bacterial stocks used for the inoculation were stored at $-20{ }^{\circ} \mathrm{C}$ in an MRS broth with $20 \%(\mathrm{v} / \mathrm{v})$ glycerol. Prior to inoculation, the aerobic cultures on MRS agar were cultivated twice for $24 \mathrm{~h}$ at $37^{\circ} \mathrm{C}$. Then, the colonies were sterilely collected from the Petri dishes, suspended in water, and used to inoculate the sprouts. To prepare the inoculum, the bacterial concentration was estimated by an optical density (OD) analysis at $600 \mathrm{~nm}$ using a Smart Spec Plus spectro- 
photometer (Bio-Rad, USA). A previously determined standard curve was applied to determine the number of Lb. rhamnosus GG cells in the suspension at a level of $1 \times 10^{8} \cdot \mathrm{ml}^{-1}$ on the basis of OD value.

\section{Sprouting conditions}

The seeds were disinfected in a $1 \%(\mathrm{v} / \mathrm{v})$ sodium hypochlorite for $10 \mathrm{~min}$, then drained and washed with distilled water until they reached neutral $\mathrm{pH}$. Next, they were soaked in distilled water $\left(\mathrm{C}-\right.$ control sample) or in a probiotic water suspension $\left(1 \times 10^{8}\right.$ CFU per $1 \mathrm{~g}$ of seeds) ( $\mathrm{S}$ - soaked with probiotics). The lentil, soy-bean, Mung bean, and Adzuki bean seeds were imbibed for [h]: 4, 4, 6, 8, respectively. The seeds (approximately $12 \mathrm{~g}$ per plate) were dark-germinated for 4 days in a growth chamber (SANYO MLR-350H) on the Petri dishes $(\phi 125 \mathrm{~mm})$ lined with an absorbent paper (relative humidity of $70 \%$ ). The seedlings were sprayed every day with $5 \mathrm{ml}$ of Milli$\mathrm{Q}$ water $(\mathrm{C}, \mathrm{S})$ or $5 \mathrm{ml}$ of probiotic water suspension (freshly prepared) on the $1^{\text {st }}$ day of cultivation $\left(1 \times 10^{8} \mathrm{CFU}\right.$ per $1 \mathrm{~g}$ of seeds) (W - watered with probiotics). Sprouting was run at $\left[{ }^{\circ} \mathrm{C}\right]: 25,30,35$. After 4 days sprouts were manually collected and analyzed.

\section{Assessing sprouting efficiency}

The seed germination percentage rate was calculated using the following formula:

$$
\text { Seed germination percentage [\%] }=\frac{\text { Number of germinated seeds }}{\text { Total number of seeds }} \times 100 \%
$$

The sprouts biomass accumulation was expressed as a mass of 10 sprouts. For each variant of sprouting, at least 100 sprouts were weighed [23].

\section{Counting Lb. rhamnosus $G G$ viable cells}

Once sprouting was completed, the samples were collected and the surface (SP) and total (TP) number of probiotic cells were counted. For SP $1 \mathrm{~g}$ of sprouts was washed with $10 \mathrm{ml}$ of Ringer's solution (10 min, $60 \mathrm{rpm})$. For TP $1 \mathrm{~g}$ of sprouts was gently homogenized with $10 \mathrm{ml}$ of Ringer`s solution and shaken for $10 \mathrm{~min}(60 \mathrm{rpm})$. Then, serial decimal dilutions of the sprout samples were made and $0.1 \mathrm{ml}$ of aliquots were placed on an MRS agar in triplicate and incubated aerobically at $37^{\circ} \mathrm{C}$ for $48 \mathrm{~h}$. The characteristic colonies were counted and their numbers were calculated as $\mathrm{CFU} \cdot \mathrm{g}^{-1}$ of fresh mass.

\section{Efficiency factor}

To sum up the final effect of the protocol as proposed for the probiotic-rich sprouts, the efficiency factor was calculated:

$$
\text { Efficiency factor }=\frac{\text { Seed germination percentage }[\%]}{\text { Total mass of sprouts }} \times \text { Amount of probiotics }
$$


Statistical analysis

All the experimental results were expressed as a mean \pm S.D. of the three parallel experiments. One-way analysis of variance (ANOVA) and Tukey's post-hoc test at a 0.05 level of significance were used to compare the groups.

\section{Results and discussion}

Currently, the development of fruits and vegetables containing probiotic strains is a highly interesting issue for consumers $[2,9,16]$. So far, legume flours or sprouted flours have been successfully used as effective prebiotics during preparation of yogurts [1], food supplements [6], or non-dairy probiotic beverages [17].

The study involved the screening of conditions for production of legume sprouts rich in $L b$. rhamnosus GG, i.e. such conditions were selected that could simultaneously ensure the effective growth of sprouts (seed germination) and the optimal survival (even stimulation of growth) of bacteria. Therefore, the effect was determined of the temperature and inoculation method on the sprouting efficiency and sprouts biomass accumulation (Tab. 1 and 2). Generally, the two bean species (Adzuki and Mung) were effectively germinated at a temperature within the studied temperature range (Tab. 1). The Adzuki bean sprouts obtained at $30^{\circ} \mathrm{C}$ and $35^{\circ} \mathrm{C}$ were characterized by a higher biomass than that of the respective control sample; however the differences were insignificant (Tab. 2). Lentil was most effectively sprouted at $25^{\circ} \mathrm{C}$, at $35^{\circ} \mathrm{C}$ a clearly visible decrease in the germination efficiency was reported: the seed germination rate was lower than $10 \%$. Similarly, in the case of the soy-bean, an undesirable effect was observed during sprouting at $35{ }^{\circ} \mathrm{C}$ and, most importantly, it was strengthened by soaking the seeds in the probiotics (a decrease of about $40 \%$ compared to the control sample) Tab. 1. The introduction of $L b$. rhamnosus into lentil seeds caused the biomass of sprouts to insignificantly increase at $25^{\circ} \mathrm{C}$ and $30^{\circ} \mathrm{C}$ compared to the respective control sample.

Generally, the temperature of sprouting played a key role in the production of probiotic sprouts; it strongly affected the germination efficiency and biomass production. The results of the germination efficiency obtained in this study (sprouting at $25^{\circ} \mathrm{C}$ and $30^{\circ} \mathrm{C}$ ) are comparable with the previous studies on sprouted legumes e.g. soy-bean [28], lentil [21], Adzuki beans [15], and Mung beans [26].

The number of viable $L b$. rhamnosus GG cells in the sprouts at the beginning of cultivation showed that the inoculation method played a crucial role in the survival of bacteria after 4 days of sprouting. The seeds (sprouts) were inoculated with water infusions $\left(1 \times 10^{8}\right.$ CFU per $1 \mathrm{~g}$ of material). As shown in Fig. 1 , the initial counts of $L b$. rhamnosus - determined after imbibition (S) or $6 \mathrm{~h}$ after spraying on the $1^{\text {st }}$ day of cultivation (W) - were significantly lower. This fact clearly pointed out that that step 
strongly determined the quality of probiotic-rich sprouts (survival of Lb. rhamnosus). A significant decrease in the probiotic population in the inoculum as well as in the seeds/sprouts was probably caused by the exposure to oxygen, which had strong effects on the Lb. rhamnosus survival in other food matrices, e.g. in apple juice [5].

Table 1. Germination efficiency as determined by effect of sprouting temperature and method of introducing probiotics

Tabela 1. Wydajność kiełkowania determinowana wpływem temperatury kiełkowania i metody wprowadzania probiotyków

\begin{tabular}{|c|c|c|c|c|c|}
\hline \multirow{3}{*}{$\begin{array}{c}\text { Sprouting } \\
\text { temperature } \\
\text { Temperatura } \\
\text { kiełkowania } \\
{\left[{ }^{\circ} \mathrm{C}\right]}\end{array}$} & \multirow{3}{*}{$\begin{array}{l}\text { Sample } \\
\text { Próba }\end{array}$} & \multicolumn{4}{|c|}{ Germination efficiency / Wydajność kiełkowania [\%] } \\
\hline & & \multicolumn{4}{|c|}{ Sprouts / Kiełki } \\
\hline & & $\begin{array}{c}\text { Lentil } \\
\text { Soczewica }\end{array}$ & $\begin{array}{l}\text { Soy-bean } \\
\text { Soja }\end{array}$ & $\begin{array}{l}\text { Adzuki bean } \\
\text { Fasola Adzuki }\end{array}$ & $\begin{array}{l}\text { Mung bean } \\
\text { Fasola Mung }\end{array}$ \\
\hline \multirow{3}{*}{25} & $\mathrm{C}$ & $86.9^{\mathrm{bc}} \pm 6.38$ & $79.8^{\mathrm{c}} \pm 3.16$ & $88.8^{\mathrm{ab}} \pm 2.22$ & $94.0^{\mathrm{bc}} \pm 1.60$ \\
\hline & $\mathrm{S}$ & $83.2^{\mathrm{C}} \pm 0.25$ & $69.7^{\mathrm{bc}} \pm 3.04$ & $89.0^{\mathrm{b}} \pm 0.53$ & $95.4^{\mathrm{c}} \pm 0.48$ \\
\hline & $\mathrm{W}$ & $78.9^{\mathrm{b}} \pm 0.89$ & $73.8^{\mathrm{bc}} \pm 2.48$ & $92.1^{\mathrm{ab}} \pm 5.42$ & $94.0^{\mathrm{b}} \pm 0.27$ \\
\hline \multirow{3}{*}{30} & $\mathrm{C}$ & $77.4^{\mathrm{bc}} \pm 4.92$ & $78.2^{\mathrm{c}} \pm 3.19$ & $86.3^{\mathrm{ab}} \pm 4.09$ & $94.7^{\mathrm{bc}} \pm 1.62$ \\
\hline & $\mathrm{S}$ & $81.4^{\mathrm{bc}} \pm 2.10$ & $72.7^{\mathrm{bc}} \pm 5.83$ & $92.0^{\mathrm{b}} \pm 2.12$ & $94.9^{\mathrm{c}} \pm 0.48$ \\
\hline & $\mathrm{W}$ & $78.1^{\mathrm{bc}} \pm 10.66$ & $75.9^{\mathrm{c}} \pm 2.95$ & $90.8^{\mathrm{ab}} \pm 2.66$ & $94.4^{\mathrm{c}} \pm 0.97$ \\
\hline \multirow{3}{*}{35} & $\mathrm{C}$ & $9.3^{\mathrm{a}} \pm 9.25$ & $69.2^{\mathrm{bc}} \pm 7.74$ & $85.3^{\mathrm{a}} \pm 2.15$ & $89.6^{\mathrm{abc}} \pm 6.75$ \\
\hline & $S$ & $6.4^{\mathrm{a}} \pm 0.25$ & $41.9^{\mathrm{a}} \pm 0.87$ & $89.2^{b} \pm 0.27$ & $91.2^{\mathrm{a}} \pm 0.48$ \\
\hline & $\mathrm{W}$ & $6.2^{\mathrm{a}} \pm 3.05$ & $63.5^{\mathrm{b}} \pm 6.66$ & $84.3^{\mathrm{ab}} \pm 4.75$ & $93.5^{\mathrm{bc}} \pm 1.58$ \\
\hline
\end{tabular}

Explanatory notes / Objaśnienia:

$\mathrm{C}$ - control sample / próba kontrolna; S - sprouts obtained from seeds soaked in probiotic / kiełki otrzymane $\mathrm{z}$ nasion namaczanych w probiotyku; $\mathrm{W}$ - sprouts watered with probiotic / kiełki podlewane probiotykiem. Table shows mean values \pm standard deviations. / W tabeli przedstawiono wartości średnie \pm odchylenia standardowe; $\mathrm{n}=3 ; \mathrm{a}, \mathrm{b}, \mathrm{c}-$ mean values in columns and denoted by different letters differ statistically significantly $(\mathrm{p} \leq 0.05)$ / wartości średnie w kolumnach oznaczone różnymi literami różną się statystycznie istotnie $(\mathrm{p} \leq 0,05)$.

In general, in the food industry, a wide range of probiotic levels (from $1 \times 10^{6}$ $\mathrm{CFU} \cdot \mathrm{g}^{-1}$ to $\left.1 \times 10^{8} \mathrm{CFU} \cdot \mathrm{g}^{-1}\right)$ is recommended as minimal in consumed foods for any health benefits [15]. Compared to the initial population, an increase in the total number of Lb. rhamnosus GG cells was detected only in the lentil and soy-bean sprouts obtained from the seeds imbibed in inoculums and further cultivated at $25{ }^{\circ} \mathrm{C}$. Those sprouts contained $3.1 \times 10^{6}$ and $7.18 \times 10^{6} \mathrm{CFU}$ per $g$ of fresh mass and, most importantly, the counts of Lb. rhamnosus as determined in the commonly consumed portions (about $50 \mathrm{~g}$ ) classified the sprouts obtained as probiotic, functional food.

So far, no study has been conducted to evaluate sprouted foods as carriers for probiotics; however, in some studies, fruits or vegetables are involved. In the study by Alegre et al. [2] fresh-cut apples were used as carriers for the probiotic Lb. rhamnosus 
GG strain. It was shown that the initial population of probiotic was stable during 28day storage under cool conditions; however, only a slight growth was determined after 5 days of storage. Furthermore, some promising results were obtained by Lavermicocca et al. [14] who investigated the table olive as a vehicle for incorporating probiotic bacterial species. Bifidobacteria and one strain of Lb. rhamnosus (Lactobacillus GG) showed a good survival rate in the selected olive samples, with a recovery of about $10^{6}$ $\mathrm{CFU} \cdot \mathrm{g}^{-1}$ after 30 days of storage. The previously cited studies demonstrated that the amount of probiotic bacteria in food products depended on the level of inoculums; their viability must be maintained throughout the product shelf life $[2,20]$. In the light of those data, the growth of Lb. rhamnosus GG in soy-bean and lentil sprouts is very promising. In the case of the beans sprouts, it was concluded that they did not provide conditions for the survival or/and growth of probiotic Lb. rhamnosus strain. Generally, the population of that strain was significantly reduced during sprouting, a slight growth was observed only in the case of sprouts obtained from the seeds imbibed in the inoculum (the probiotics did not reach the initial amounts) - Fig. 1. Vesterlund et al. [25] suggested that the viability of $L b$. rhamnosus GG was less dependent on the matrix used but it was strongly dependent on the activity of water and its content in a food matrix. During soaking the beans sprouts absorbed about 2 - 3 times lower amounts of water compared to the soy-bean and lentil seeds. Thus, the losses observed in the probiotic population at the initial stages of germination might have been caused by such factors as a lower activity of water and oxygen isolation as well as by a decreased

Table 2. Biomass accumulation as determined by sprouting temperature and probiotics added

Tabela 2. Przyrost biomasy kiełków determinowany temperaturą kiełkowania i dodatkiem probiotyków

\begin{tabular}{|c|c|c|c|c|c||}
\hline \multirow{2}{*}{$\begin{array}{c}\text { Sprouting } \\
\text { temperature } \\
\begin{array}{c}\text { Temperatur } \\
\text { kiełkowania } \\
{\left[{ }^{\circ} \mathrm{C}\right]}\end{array}\end{array}$} & \multicolumn{5}{|c||}{ Mass of 10 sprouts / Masa 10 kiełków [g] } \\
\cline { 2 - 6 } & $\begin{array}{c}\text { Sample } \\
\text { Próba }\end{array}$ & $\begin{array}{c}\text { Lentil } \\
\text { Soczewica }\end{array}$ & $\begin{array}{c}\text { Soy-bean } \\
\text { Soja }\end{array}$ & $\begin{array}{c}\text { Adzuki bean } \\
\text { Fasola Adzuki }\end{array}$ & $\begin{array}{c}\text { Mung bean } \\
\text { Fasola Mung }\end{array}$ \\
\hline \multirow{3}{*}{25} & $\mathrm{C}$ & $1.31^{\mathrm{a}} \pm 0.03$ & $2.53^{\mathrm{b}} \pm 0.11$ & $1.47^{\mathrm{ab}} \pm 0.09$ & $1.41^{\mathrm{ab}} \pm 0.12$ \\
\cline { 2 - 7 } & $\mathrm{S}$ & $1.36^{\mathrm{ab}} \pm 0.09$ & $2.36^{\mathrm{abc}} \pm 0.33$ & $1.37^{\mathrm{ab}} \pm 0.13$ & $1.29^{\mathrm{a}} \pm 0.10$ \\
\cline { 2 - 7 } & $\mathrm{W}$ & $1.32^{\mathrm{ab}} \pm 0.09$ & $2.39^{\mathrm{abc}} \pm 0.33$ & $1.53^{\mathrm{abc}} \pm 0.13$ & $1.28^{\mathrm{a}} \pm 0.05$ \\
\hline \multirow{3}{*}{30} & $\mathrm{C}$ & $1.43^{\mathrm{bc}} \pm 0.09$ & $2.51^{\mathrm{bc}} \pm 0.22$ & $1.57^{\mathrm{bc}} \pm 0.07$ & $1.45^{\mathrm{ab}} \pm 0.11$ \\
\cline { 2 - 7 } & $\mathrm{S}$ & $1.52^{\mathrm{bc}} \pm 0.09$ & $2.13^{\mathrm{a}} \pm 0.04$ & $1.67^{\mathrm{bc}} \pm 0.09$ & $1.51^{\mathrm{b}} \pm 0.05$ \\
\cline { 2 - 7 } & $\mathrm{W}$ & $1.47^{\mathrm{bc}} \pm 0.15$ & $2.92^{\mathrm{bc}} \pm 0.16$ & $1.60^{\mathrm{abc}} \pm 0.16$ & $1.37^{\mathrm{ab}} \pm 0.20$ \\
\hline \multirow{3}{*}{35} & $\mathrm{C}$ & $1.29^{\mathrm{ab}} \pm 0.10$ & $2.31^{\mathrm{ab}} \pm 0.35$ & $1.46^{\mathrm{a}} \pm 0.02$ & $1.35^{\mathrm{a}} \pm 0.10$ \\
\cline { 2 - 7 } & $\mathrm{S}$ & $1.19^{\mathrm{a}} \pm 0.09$ & $2.45^{\mathrm{abc}} \pm 0.45$ & $1.58^{\mathrm{b}} \pm 0.08$ & $1.53^{\mathrm{ab}} \pm 0.16$ \\
\cline { 2 - 7 } & $\mathrm{W}$ & $1.24^{\mathrm{ab}} \pm 0.15$ & $2.52^{\mathrm{b}} \pm 0.11$ & $1.61^{\mathrm{abc}} \pm 0.18$ & $1.51^{\mathrm{b}} \pm 0.05$ \\
\hline
\end{tabular}

Explanatory notes as in Tab. 1. / Objaśnienia jak pod tab. 1. 

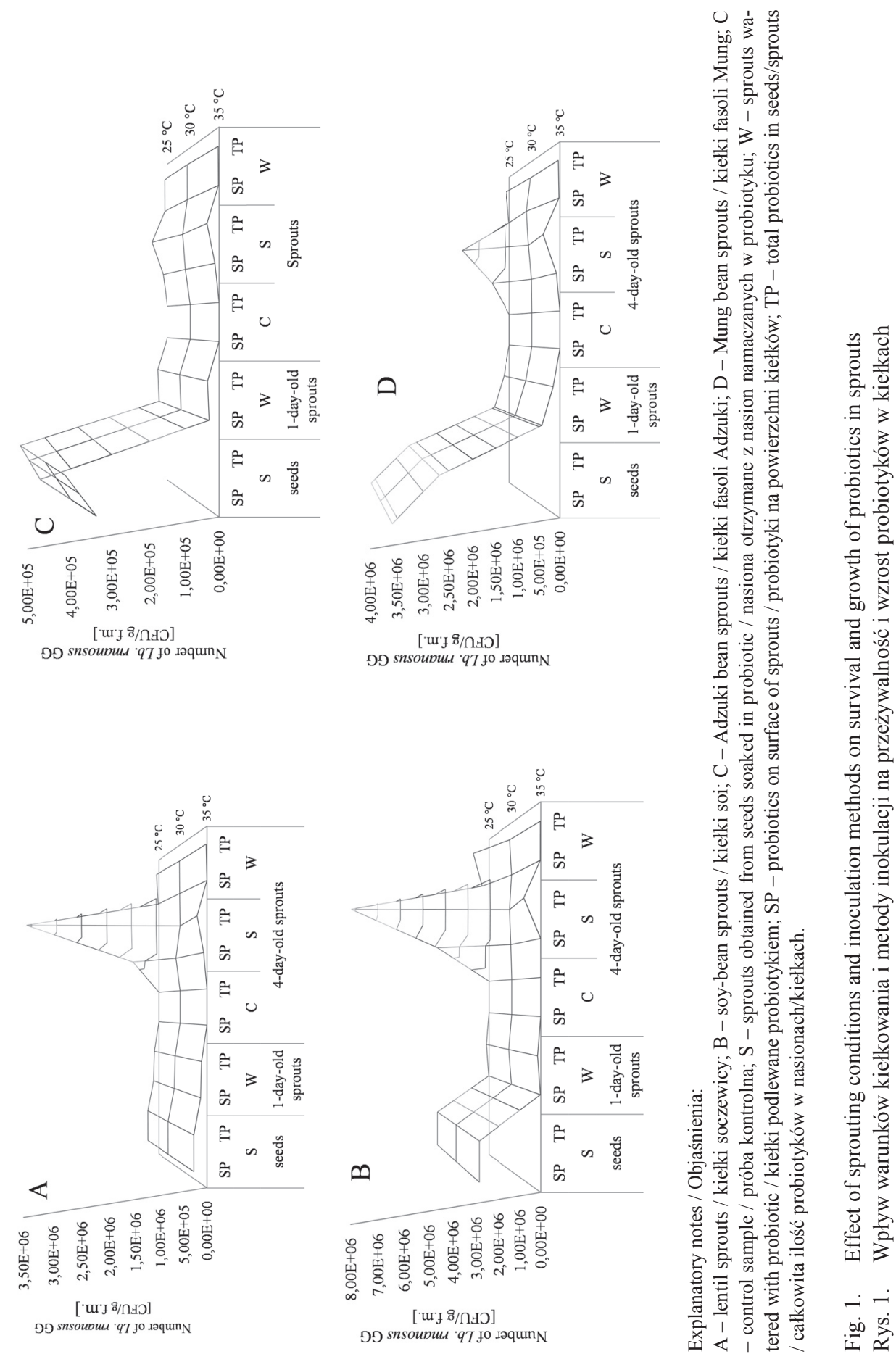


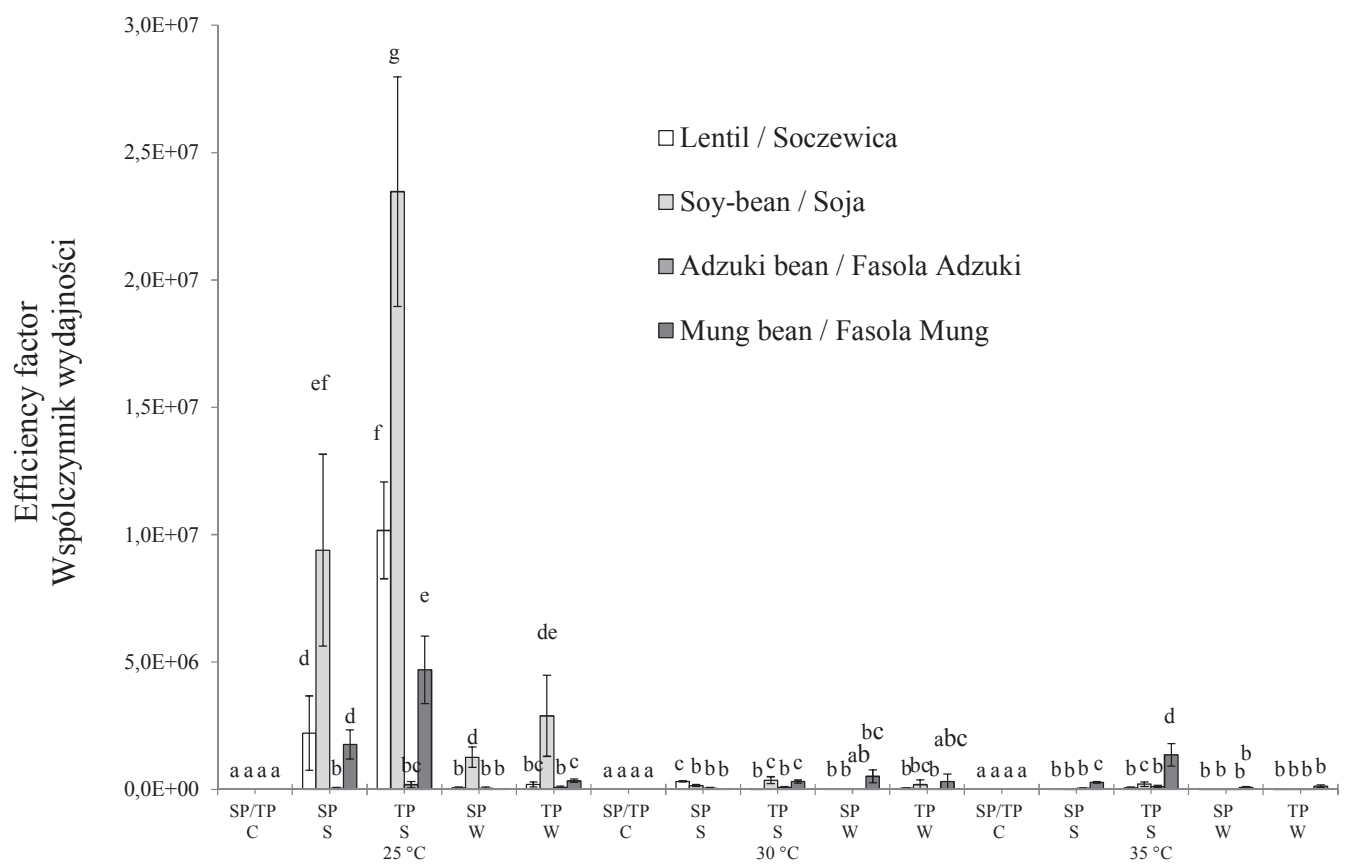

Explanatory notes / Objaśnienia:

C - control sample / próba kontrolna; S - sprouts obtained from seeds soaked in probiotic / kiełki otrzymane $\mathrm{z}$ nasion namaczanych $\mathrm{w}$ probiotyku; $\mathrm{W}$ - sprouts watered with probiotic / kiełki podlewane probiotykiem; SP - probiotics on surface of sprouts / probiotyki na powierzchni kiełków; TP - total probiotics in seeds/sprouts / całkowita ilość probiotyków w nasionach/kiełkach.

Mean values ( \pm standard deviations) denoted by different letters differ statistically significantly $(\mathrm{n}=3, \mathrm{p}=$ 0.05 / Wartości średnie ( \pm odchylenia standardowe) oznaczone różnymi literami różnią się statystycznie istotnie $(\mathrm{n}=3 ; \mathrm{p}=0,05)$.

Fig. 2. Effect of sprouting conditions and inoculation methods on production of probiotic-rich sprouts

Rys. 2. Wpływ warunków kiełkowania i metody inokulacji na produkcję kiełków bogatych w probiotyki

availability of nutrients (loose seed structure and inadequate activity of enzymes responsible for mobilization of storage materials). Since the conditions optimal for the growth of probiotics (survival) and sprout development are not always the same, an efficiency factor is suggested in the study. It combines the results of the germination rate, biomass accumulation, and the number of probiotic bacteria cells (Fig. 2). The values of the efficiency factors determined in the study clearly pointed out that the soybean sprouts were the best carriers for Lb. rhamnosus GG. Based on the efficiency factor, it was verified that the lentil sprouts (that had comparable amounts of probiotic bacteria - Fig. 1) were not predisposed for to be carriers for Lb. rhamnosus GG: they were characterized by a lower germination efficiency and biomass accumulation. 
The study provides some promising results; however, a detailed evaluation of probiotic preparation based on legume sprouts and Lb. rhamnosus requires additional studies on the survival of probiotic strain during storage and digestion as well as changes in the nutritional and nutraceutical quality of sprouts.

\section{Conclusions}

1. Legume sprouts may be used as carriers for Lb. rhamnosus GG.

2. A number of probiotic bacteria in sprouts are strongly determined by the germination temperature, inoculation methods, and legume species.

3. Lentil and soy-bean sprouts obtained at $25^{\circ} \mathrm{C}$ were the most effective carrier for the probiotic strain studied.

4. Due to the fact that soy-bean seeds ensure both the growth and the biomass accumulations of sprouts and probiotic bacteria, they are the best material for the production of Lb. rhamnosus-rich sprouts.

\section{Acknowledgements}

This study was supported by the National Science Centre, Poland (NCN) [Grant OPUS No. 2015/17/B/NZ9/01797].

\section{References}

[1] Agil R., Gaget A., Gliwa J., Avis T.J., Willmore W.G., Hosseinian F.: Lentils enhance probiotic growth in yogurt and provide added benefit of antioxidant protection. LWT - Food Sci. Technol., 2013, 50 (1), 45-49.

[2] Alegre I., Viñas I., Usall J., Anguera M., Abadias M.: Microbiological and physicochemical quality of fresh-cut apple enriched with the probiotic strain Lactobacillus rhamnosus GG. Food Microbiol., 2011, 28 (1), 59-66.

[3] Al-Sheraji S.H., Ismail A., Manap M.Y., Mustafa S., Yusof R.M., Hassan F.A.: Prebiotics as functional foods: A review. J. Funct. Foods., 2013, 5 (4), 1542-1553.

[4] Baena R., Salinas P.: Diet and colorectal cancer. Maturitas, 2015, 80 (3), 258-264.

[5] Champagne C.P., Raymond Y., Gagnon R.: Viability of Lactobacillus rhamnosus R0011 in an apple - based fruit juice under simulated storage conditions at the consumer level. J. Food Sci., 2008, 73 (5), 221-226.

[6] De Boever P., Wouters R., Verstraete W.: Combined use of Lactobacillus reuteri and soygerm powder as food supplement. Lett. Appl. Microbiol., 2001, 336, 420-424.

[7] Do Espírito Santo A.P., Perego P., Converti A., Oliveira M.N.: Influence of food matrices on probiotic viability - A review focusing on the fruity bases. Trends Food Sci. Technol., 2011, 22 (7), 377385.

[8] Duranti M.: Grain legume proteins and nutraceutical properties. Fitoterapia, 2006, 77 (2), 67-82.

[9] Endo A., Teräsjärvi J., Salminen S.: Food matrices and cell conditions influence survival of Lactobacillus rhamnosus GG under heat stresses and during storage. Int. J. Food Microbiol., 2014, 17 (174), 110-112.

[10] Dziki D., Gawlik-Dziki U., Kordowska-Wiater M., Domań-Pytka M.: Influence of elicitation and germination conditions on biological activity of wheat sprouts. J. Chem., 2015, \#649709, 1-8.

[11] Hoover R., Zhou Y.: In vitro and in vivo hydrolysis of legume starches by $\alpha$-amylase and resistant starch formation in legumes - a review. Carbohydr. Polym. 2003, 54 (4), 401-417. 
[12] Johnson C.R., Thavarajah D., Combs G.F., Thavarajah P.: Lentil (Lens culinaris L.): A prebioticrich whole food legume. Food Res. Int., 2013, 51 (1), 107-113.

[13] Kalogeropoulos N., Chiou A., Ioannou M., Karathanos V.T., Hassapidou M., Andrikopoulos N.K.: Nutritional evaluation and bioactive microconstituents (phytosterols, tocopherols, polyphenols, triterpenic acids) in cooked dry legumes usually consumed in the Mediterranean countries. Food Chem., 2014, 121 (3), 682-690.

[14] Lavermicocca P., Valerio F., Lonigro S.L., De Angelis M., Morelli L., Callegari M.L., Rizzello C.G., Visconti A.: Study of adhesion and survival of lactobacilli and bifidobacteria on table olives with the aim of formulating a new probiotic food. Appl. Environ. Microbiol., 2005, 71, 4233-4240.

[15] Limón R.I., Peñas E., Martínez-Villaluenga C., Frias J.: Role of elicitation on the health-promoting properties of kidney bean sprouts. LWT - Food Sci. Technol., 2014, 56 (2), 328-334.

[16] Martins E.M.F., Ramos A.M., Vanzela E.S.L., Stringheta P.C., de Oliveira Pinto C.L., Martins J.M.: Products of vegetable origin: A new alternative for the consumption of probiotic bacteria. Food Res. Int., 2013, 51 (2), 764-770.

[17] Mridula D., Sharma M.: Development of non-dairy probiotic drink utilizing sprouted cereals, legume and soymilk. LWT - Food Sci. Technol., 2015, 62 (1), 482-487.

[18] Possemiers S., Marzorati M., Verstraete W., van de Wiele T.: Bacteria and chocolate: A successful combination for probiotic delivery. Int. J. Food Microbiol., 2010, 141(1-2), 97-103.

[19] Ranadheera R.D.C.S., Baines S.K., Adams M.C.: Importance of food in probiotic efficacy. Food Res. Int., 2010, 43 (1), 1-7.

[20] Shimakawa Y.: Evaluation of Bifidobacterium breve strain Yakult-fermented soymilk as a probiotic food. Int. J. Food Microbiol., 2003, 81 (2), 131-136.

[21] Świeca M., Gawlik-Dziki U., Kowalczyk D., Złotek U.: Impact of germination time and type of illumination on the antioxidant compounds and antioxidant capacity of Lens culinaris sprouts. Sci. Hortic., 2012, 140, 87-95.

[22] Świeca M., Baraniak B., Gawlik-Dziki U.: In vitro digestibility and starch content, predicted glycemic index and potential in vitro antidiabetic effect of lentil sprouts obtained by different germination techniques. Food Chem., 2013, 138 (2-3), 1414-1420.

[23] Świeca M., Baraniak B.: Nutritional and antioxidant potential of lentil sprouts affected by elicitation with temperature stress. J. Agric. Food Chem., 2014, 62 (14), 3306-3313.

[24] Tripathi M.K., Giri S.K.: Probiotic functional foods: Survival of probiotics during processing and storage. J. Funct. Foods., 2014, 9, 225-241.

[25] Vesterlund S., Salminen K., Salminen S.: Water activity in dry foods containing live probiotic bacteria should be carefully considered: A case study with Lactobacillus rhamnosus GG in flaxseed. Int. J. Food Microbiol., 2012, 157 (2), 319-321.

[26] Vidal-Valverde C., Frias J., Sierra I., Blazquez I., Lambein F., Kuo Y.H.: New functional legume foods by germination: Effect on the nutritive value of beans, lentils and peas. Eur. Food Res. Technol., 2002, 215 (6), 472-477.

[27] Walsh C.J., Guinane C.M., O’Toole P.W., Cotter P.D.: Beneficial modulation of the gut microbiota. FEBS Lett., 2014, 588 (22), 4120-4130.

[28] Yun J., Li X., Fan X., Li W., Jiang Y.: Growth and quality of soybean sprouts (Glycine max L. Merrill) as affected by gamma irradiation. Radiat. Phys. Chem., 2013, 82, 106-111.

\title{
ZASTOSOWNIE KIEŁKÓW WYBRANYCH ROŚLIN STRĄCZKOWYCH JAKO NOŚNIKA DLA LACTOBACILLUS RHAMNOSUS GG - BADANIA PRZESIEWOWE
}

\author{
Streszczenie
}

Probiotyki i prebiotyki odgrywają ważna rolę w żywieniu zwierząt i człowieka. W badaniach oceniono możliwość zastosowania kiełków roślin strączkowych jako nośników probiotycznych bakterii Lac- 
tobacillus rhamnosus GG. W pracy określono wpływ gatunku rośliny, temperatury kiełkowania, metody inokulacji nasion lub wzrastających już kiełków na przeżywalność i/lub wzrost probiotyków w kiełkach.

Stwierdzono, że liczba bakterii w kiełkach zależała od temperatury prowadzenia hodowli, metody inokulacji, jak też gatunku rośliny zastosowanej jako nośnik. Badane fasole (Adzuki oraz Mung) efektywnie kiełkowały w zakresie temp. $25 \div 35^{\circ} \mathrm{C}$. Soczewica natomiast najwydajniej kiełkowała w temp. $25^{\circ} \mathrm{C}$. W przypadku kiełków soczewicy i soi temperatura $35^{\circ} \mathrm{C}$ wpłynęła na zmniejszenie wydajności kiełkowania. Wzrost Lb. rhamnosus GG stwierdzono tylko w przypadku kiełków soczewicy i soi otrzymanych z nasion namoczonych w inokulum i kiełkowanych w temp. $25^{\circ} \mathrm{C}$. Ich liczba w kiełkach wynosiła odpowiednio $3.1 \times 10^{6} \mathrm{i} 7.18 \times 10^{6} \mathrm{jkt} / \mathrm{g}$ świeżej masy. Kiełki uzyskane z nasion analizowanych fasoli nie zapewniały warunków do przeżywalności i wzrostu bakterii probiotycznych. Najlepszym nośnikiem badanych bakterii probiotycznych były nasiona soi, w przypadku których w temp. $25^{\circ} \mathrm{C}$ otrzymano kiełki o najlepszych parametrach jakościowych po zastosowaniu inokulacji nasion zawiesiną bakterii probiotycznych.

Słowa kluczowe: rośliny strączkowe, kiełki, probiotyki, Lb. rhamnosus

\section{Wydzial Nauk o Żywności i Biotechnologii \\ Uniwersytetu Przyrodniczego w Lublinie \\ Polskie Towarzystwo Technologów Żywności}

Sekcja Młodej Kadry Naukowej Polskiego Towarzystwa Technologów Żywności

Sekcja Chemii Żywności Polskiego Towarzystwa Chemicznego

zapraszają na

\section{Sesję Naukową Sekcji Młodej Kadry Naukowej „Żywność - tradycja i nowoczesność"}

Lublin, 24 - 25 maja 2018 r.

Tematyka Sesji:

- Technologia i biotechnologia żywności

- Prozdrowotne cechy żywności

- Trendy w żywieniu człowieka

- Jakość i bezpieczeństwo żywności

- Inżynieria przetwórstwa żywności

- Żywność regionalna i tradycyjna

Informacje: www.mkn.ultra.edu.pl

Kontakt:

Sekretarz sesji: dr Urszula Złotek - tel. (81) 4623328

e-mail: smknlublin@up.lublin.pl 